\title{
CHEMICAL CHARACTERIZATION OF THE TER RIVER
}

\author{
F. Sabater, J. Armengol \\ Dpto. de Ecologia. Facultad de Biología. Universidad de Barcelona.
}

Palabras clave: River, water chemistry, mineralization, salinity, contamination, succession.

\section{RESUMEN}

CARACTERIZACION QUIMICA DEL RIO TER

\begin{abstract}
A partir del estudio mensual de 18 variables físico-químicas en 30 estaciones del río Ter se han establecido los factores más importantes que determinan su estructura y funcionamiento como ecosistema. El tratamiento global de los datos obtenidos a lo largo de 12 muestreos se ha realizado mediante un análisis de Componentes Principales. Los resultados obtenidos muestran, que el incremento en la mineralización del agua a lo largo del río, y los cambios en el caudal que se producen durante al año son los factores más importantes para determinar la dinámica del río Ter.

El primer componente principal está claramente asociado a la organización longitudinal del río, lo que nos ha permitido obtener una medida de la distorsión que se produce en la imagen del río como consecuencia de los procesos químicos que tienen lugar en cada segmento estudiado, y que es, a su vez, una medida de su dinámica.
\end{abstract}

\section{INTRODUCTION}

The chemical composition of river water depends on many factors, some internal ones and others external to the system. Among the latter we can mention the intrinsec characteristics of the watershed (i.e. geological and edaphological structure, vegetatiori and topography). human activities (urbanization, agriculture and industry), and climatology (rainfall its dissolved substances). As far as the internal factors are concerned the activity of the organisms is particularly noteworthy for its modification of the environmental conditions (Margalef, 1960, 1983; Gorham, 1961: Gibbs, 1970). Even though it is hard to quantify the incidence of each of these factors, Capblanq \& Tourenq (1978) consider that in temperate regions the chemical composition of the water depends mainly on the erosion and dissolution of the rocks and soils of the watershed. together with the human activities. Thcse factors are preciselv the same ones that seem to have the most important effect on the chemical composition of the Ter river and thus have been chosen to explain the temporal and spatial variability in this study. An attempt has been made to order the different stretches of the river using a strictly environmental criteria. with the object of thus reflecting both the

Limnética 2: 75-84 (1986)

(c) Asociación Española de Limnologia. Madrid. Spain structure of the river and how it works. using as base the changes brougth upon by perturbations in the watershed. Likewise tlie chemical characterization that arises from this study can be related to the different biological communities studied: phytobentos (Sabater \& Sabater, in prep.), macrophytes (Peñuelas \& Sabater, in prep.) macroinvertebrates (Puig of $a l$, in press). and the interstitial fauna now under study.

\section{STUDY AREA}

The basin of the Ter river covers an area of 3.010 $\mathrm{Km}^{2}$, almost in its entirety in the province of Girona. From its source in the Oriental Pyrinees at 2.400 m.a.s.l, it runs a course of $208 \mathrm{Km}$., mostly over a calcareous substratum. Its source are some of the afluents to the right-handed side (Riera Major, Osor. Onyar) are situated on siliceous-type Palcozoic material , while others are over areas with gypsum (Fig. $1)$.

The river has a Mediterrancan-type regime with an average annual flow volume of $840 \mathrm{Hm}^{3}$. This value can vary considerably in successive years as well as being very irregularly distributed troughout the year. The reservoirs of Sau, Susqueda and Pasteral are lo- 


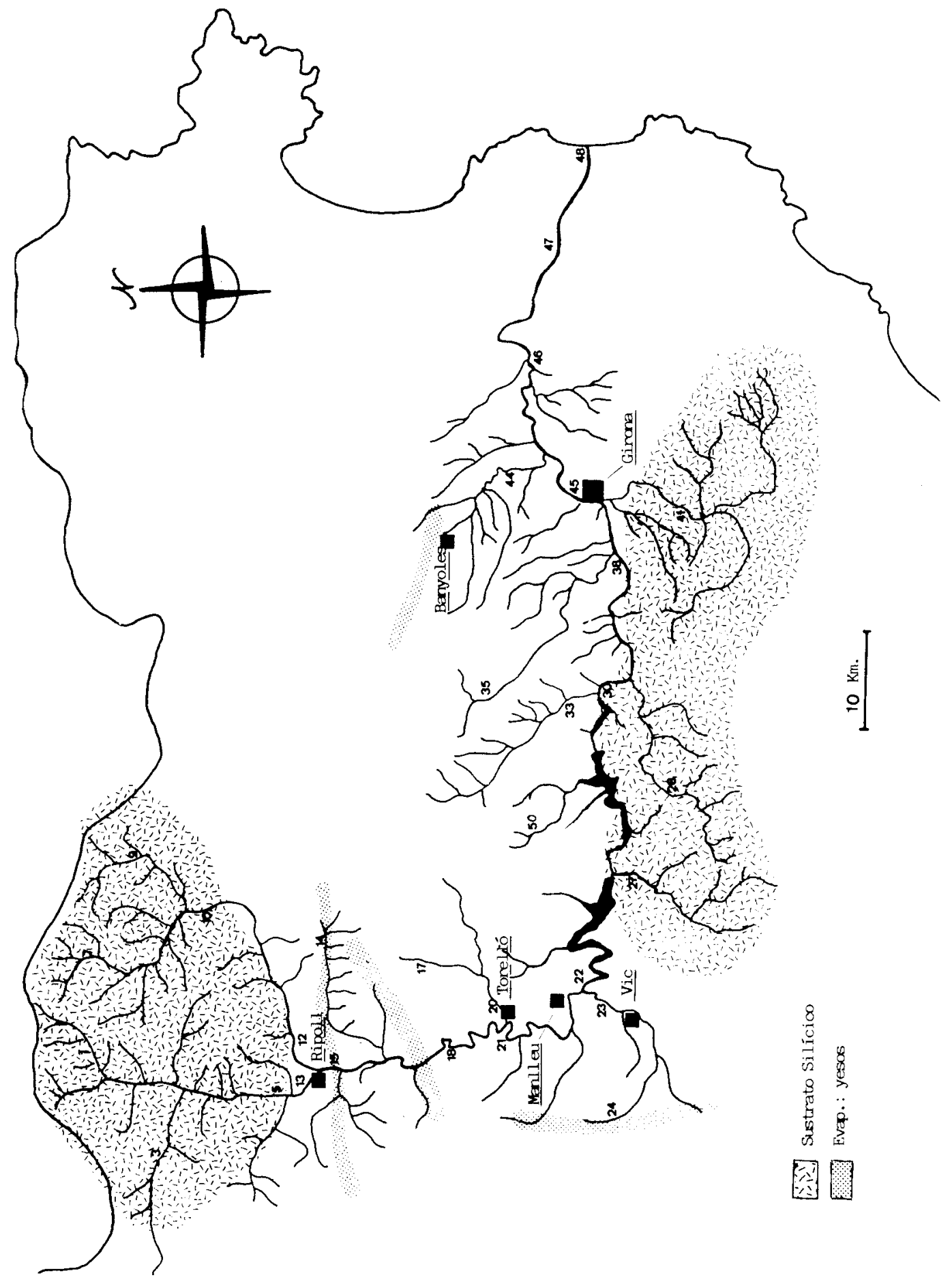

Figure 1.-Map of the drainage basin of the Ter river showing the situation of the sampling stations, main cities and the distnbution of the main geological substrates.

Mapa de la cuenca del río Ter mostrando la localización de las estaciones estudiadas, las ciudades más importantes y la distribución de los principales tipos de sustrato geologico. 
cated in the middle section. The joint capacity of the three reservoirs is $402 \mathrm{Hm}^{3}$ and the average residence times are 117. 146 and 1.3 days respectively. The incidence as a whole on the physical-chemical and biological characteristics of the lower stretch of the river is notable.

According to the 1981 census, the population of the watershed is 368,644 , but the irregular distribution forming a few important cities of considerable industrial development leads to a focalized pollution.

\section{MATERIAL AND METHODS}

Thirty stations throughout the hydrographic network of the Ter river were studied for a year-long period starting in October 1982 (Fig. 1). Monthly measurements were taken of ph, temperature, conductivity and Oxygen concentration at each point. At the same time samples were taken for posterior analyses in the laboratory of the following chemical parameters: alkalinity, concentration of chloride, sulphate, ammonium, nitrate, nitrite, phosphate, silicate, sodium, potassium, calcium, magnesium and iron. These analyses were carried out according to the methodology gathered by Margalef et al., (1976) except for those of chloride and ammonium which were measured using Orion model selective electrodes.

In addition to the aforementioned variables at each station, the following parameters were calculated: natural and accumulated drainage surface, water volume, distance to the mouth, altitude, annual precipitation, $n_{\text {l) }}$ oxygen saturation and sampling date expressed by ordering the time in days.

For the statistical processing of the data, a principal component analysis (PCA) was carried out following the package of statistic programs BMDP,. after transforming the data applying $\mathrm{X}=\log (\mathrm{X}+0,01)$ so as to stabilize the variance (Ibáñez, 1971; Estrada, 1975; Flos, 1979).

\section{RESULTS}

A principal component analysis was carried out on the obtained results so as to form groups of variables whose dynamics are similar in the studied samples and thus establish an ordering of the different river stretches and affluents. Figure 2 shows the distribution of the variables in the space formed by the first three components, which explain a total of $60 \%$ of the variance.

The first component ( $38 \%$ of the variance) is strongly correlated a to group of variables such are the conductivity, alkalinity, concentration of chloride, sulphate, calcium, sodium, potassium and magnes- sium which jointly determine the mineralization of the water, parameter which can be simply expressed with the conductivity value. Other variables like pluviosity, distance to the mouth, and altitude above sea level are negatively correlated to this component. This can be interpreted in relation to the fact that in the upper stretches of the river, located in the Pyrinees, the rainfall is greater and the salt content lower.

The second component is most closely related to a group of variables that are not in direct associaton with the chemical composition of the water such are water volume, area of the watershed, and date of sampling. This last variable has a strong negative correlation, while the first two are positively correlated $(-0.4,0.85$ and 0.75 respectively). The antagonic and extreme relative position of the two groups of variables along this axis can be interpreted as an expression of the particular distribution of water volume througthout the study period. That is, the first samples were taken in the season of greatest rainfall, while the last ones coincided with a dry period. The high correlation between the variables, water volume and area is due to the fact that in those stations for which flow data was not available, these were calculated by means of a formula in which the most important factor was the area of the basin whose waters were gathered al each station.

Lastly the third component ( $9 \%$ of the variance) holds a positive correlation with the oxygen concentration, the oxygen saturation \%, and the $\mathrm{pH}$. Only the silicate concentration is found at the opposite end of the axis in a somewhat isolated position. It is hard to explain the relation between these two groups of variables in chemical or biological terms. Seemingly this particular situation appears because those stations of low oxygen content of the water coincide with those over a siliceous substrate. On the other hand the high and significative correlation of the oxygen concentration and $\mathrm{pH}$ with the third component suggest a close relationship with the oxidizing or reducing conditions observed al each point of the river.

Ordering the stations within the space determined by the first three components enables us to complement the information already obtained from the distribution of the variables. As can be seen in figure 3, the first component orders the stations according to the longitudinal sequence from source to mouth, and corresponds with an increasing mineralization in the same direction. Only station 22 is out place in this natural sequence and it is because it recives the highly polluted inflow of the Gurri river (station 23). Immediately after this point are situated the reservoirs of Sau, Susqueda and Pasteral and thanks to the physical-chemical processes that take place in them, a recuperation of the conditions of the previous stations is observed. 

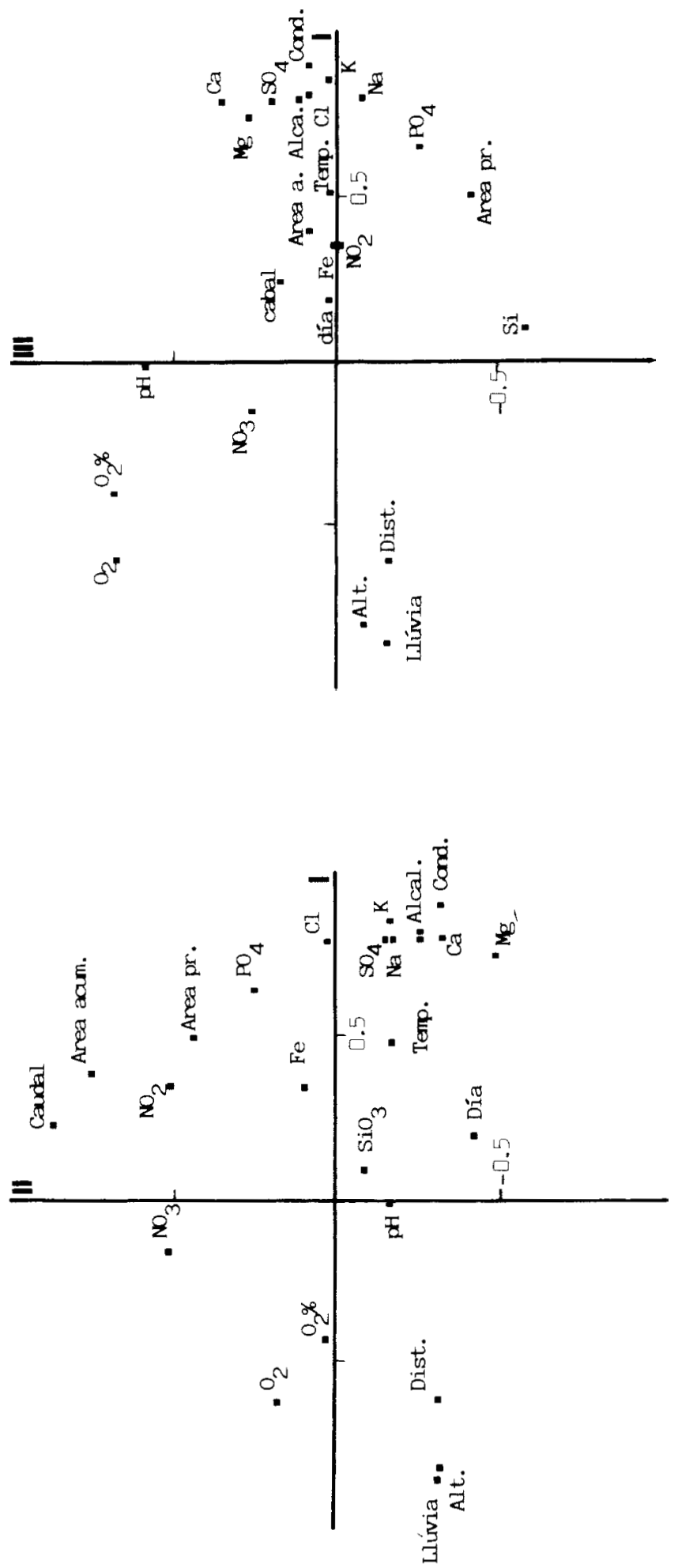

Figure 2.-Distribution of the studied variables in the spaces determined by: A) principal components I and II, B) I and III. Distribución de las variables estudiadas en los espacios formados: A) por los componentes principales 1 y 11, y B) I y III 

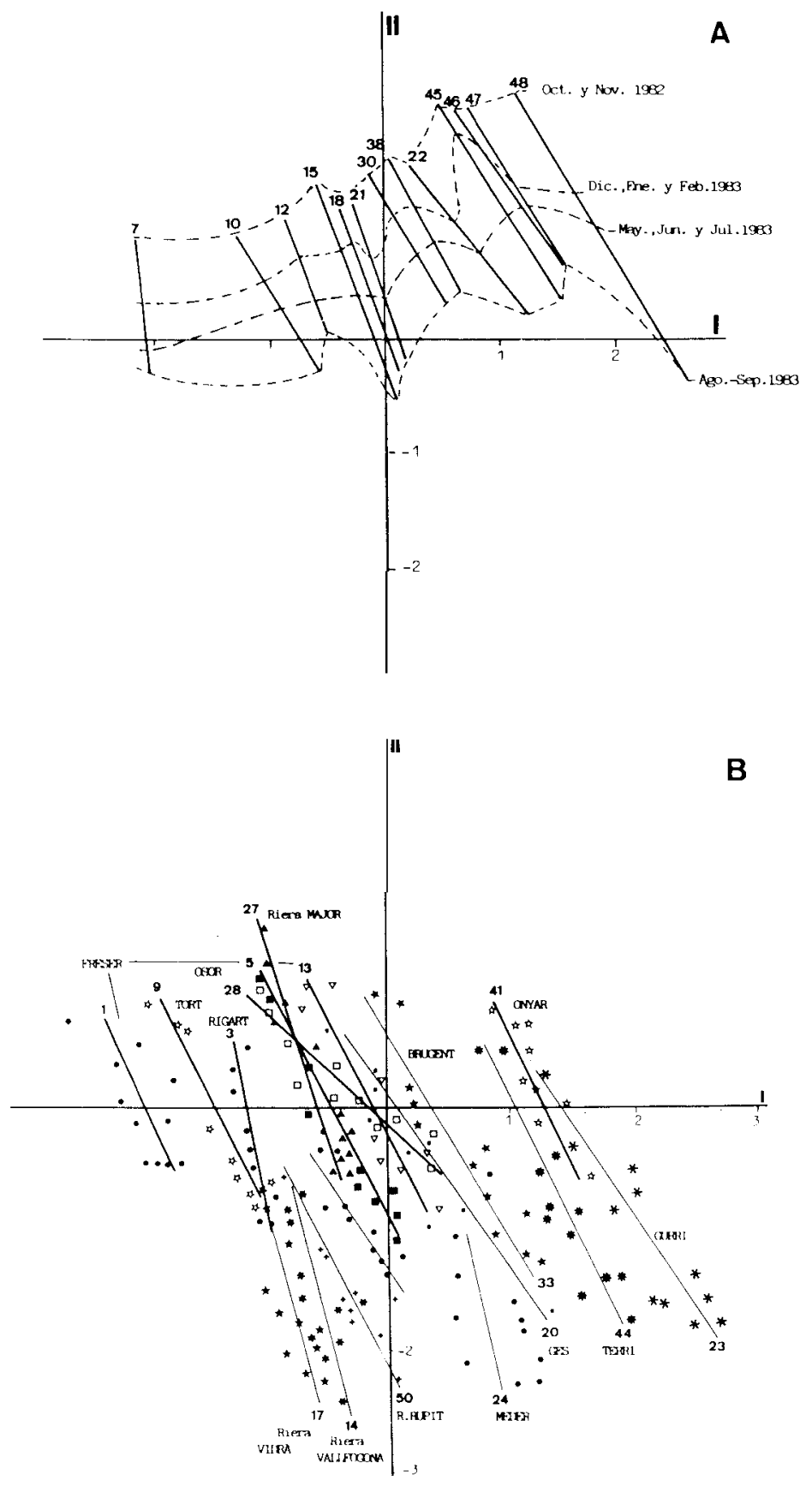

Figure 3.-Distribution of the sampling stations within the space determined by the first two principal components: A) Representation of the stations located along the river course. The regression curve of the different sampling periods has been drawn for each one. B) Same representation for the affluent stations. The thick line is for the stations over siliceous substrate and the fine one is for those over calcareous areas.

Distribución de las estaciones de muestreo en el espacio formado por los dos primeros componentes principales. A) Representación de las estaciones situadas en el eje del río. Para cada una se ha dibujado la recta de regresión de los distintos muestreos tal y como se muestra en la figura B. B) Idéntica representación para las estaciones situadas en los afluentes. En trazo grueso se dibuja la recta de regresión de las estaciones situadas en afluentes sobre sustrato silícico y en trazo fino los que se sitúan en zonas calizas. 


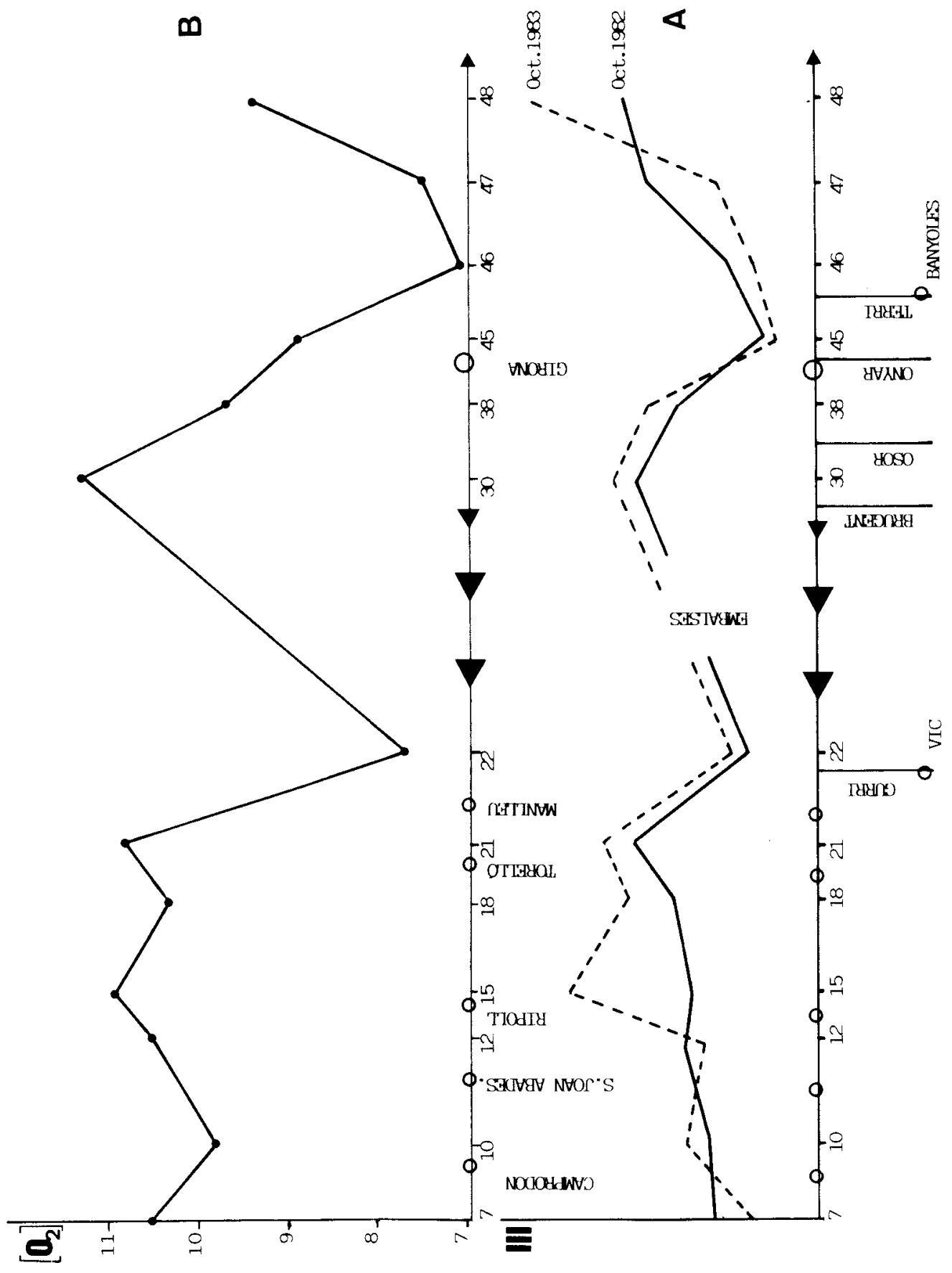

Figure 4.-A)Distnbution of the values of the third principal component for the samples in the nver course of the October 1982 and 1983. B) Average oxygen concentration for each station of the river course. The fluctuations in space are similar to those of figure A.

A) Distribución de valores del tercer componente principal para las muestras de Octubre de 1982 y de 1983 en el eje del no. B) Concentración media de oxígeno para cada estación del eje del río, que muestra unas fluctuaciones similares en el espacio a las de la figura A. 
The second component expresses the variations in time of the chemical composition of the water as consequence of the variations in volume. Throughout the year, the 12 samples are ordered along this axis in a sequence that goes from the periods of peak flow to those of low water levels.

As a direct result of ordering the stations, the combination of the first and second components (fig.3) reveals the variations in the chemical composition both along the course and during the study period. When applying this same outline to the affluent, the same dynamics are observed, although two different groups can be distinguished according to the water volume carried. Both in the case of the main course and that of the affluents, the dispersion observed in a given station within this reference space is a good estimate of its general chemical composition variability.

Figure 4 shows the stations ordered according to the third component and the relationship between it and the oxygen concentration. The most polluted points of the river stand out for possessing the most negative values. The relevance of the reservoirs for the recuperation of pristine conditions is also clearly expressed. Following this criteria, the most polluted affluents in order of increasing pollution are: Gurri, Onyar, Terri and Brugent. All of these have in common the possession of important population nuclei in their basin with considerable farming or industrial activity in relation to the water volume carried.

\section{DISCUSSION}

The spatial organization of the Ter river stands out in the structure of the Ter river. From a chemical point of view this organization appears as a consequence of the increase of dissolved salts throughout its course. This is a general characteristics of most of the world rivers (Margalef, 1983), and its most important practical consequence is the stabilization of the chemical composition of the water (Margalef, 1983). This effect is clearly observable in the Ter river as can be seen in figure 5 . This figure shows the differences between geographical and chemical distances for each station, taking as chemical distance the values of the first principal component in kilometers and normalized for the actual length of the river. According to this figure, in the riverhead, stations 7 and 12 are more differentiated chemically than what corresponds to their geographic proximity. This is consequence of the effect of the small polluted discharges (Camprodon, Sant Joan de les Abadeses) on a unbuffered and little mineralized water. Further downstream, stations 15 and 21 present a much more uniform composition, and it can be interpreted as the acquisition of a certain chemical inertia, because there are important cities in this area (Ripoll, Torelló, Manlleu). The junction of the Ter and Gurri -a true open- air sewage conduct coming from the city of Vic- gives way to the most drastic change of the whole river course. In fact, as far as chemical composition is concerned, station 22 appears in a position much further downstream in the river, and is situated closer to the city of Girona, another important source of pollution. From this point on and as result of the reservoirs, the characteristics of the river change totally because of the self-depuration processes that take place there and of the regularization of water flow and temperature of the lower stretches of the river. After stations 30 and 38 the river inputs all of kinds of pollutants (stations 45 to 47 ), which despite being the most important of the whole watershed do not have an appreciable influence on the salt composition and concentration of the water. In fact this last stretch is characterized for the coincidence between the geographical and chemical distances, revealing in this a the chemical stability acheived in the water. Only station 48 , close to the river mouth, has a somewhat different composition because of the marine influence in the last stretch, especially during storms.

The slope of the straight line drawn connecting two successive stations is an expression of the rate of exchange between them, as it is the derivate of the mineralization in function of space (Fig. 5). High values of this derivative indicate important changes in the salt concentration, as in stations $10,22,45$ and 48 . To the contrary, values below unity imply a much greater similarity in the geographical separation. If additionally the slope has a negative sing, it means that there is a decrease in the mineralization, as takes place for example due to the effect of the reservoirs or because of dilution at the junction of littlemineralized affluents.

It has been suggested that spatial evolution of a river is parallel to an ecological succession (Margalef, 1960,1983 ). Under this point of view, figure 5 would express the damping of environmental fluctuations in the same way as occurs throughout the succession in terrestrial ecosystems.

The temporal variations that take place in the river are due principally to changes in the water flow. As has been stated repeatedly, the rivers of Mediterranean regimes have aperiodic water flow fluctuations, which are reflected in the chemical component of the water. In figure 6, this relationship applied for the Ter is portrayed by comparing the differences in the values for the first component for the stations with the water volume carried by the river at different times of the year. In this figure it can be seen that the length of the river expressed in terms of mineralization is negatively correlated $(r=-0,58)$ with the water volume. To express it somewhat more graphically we 

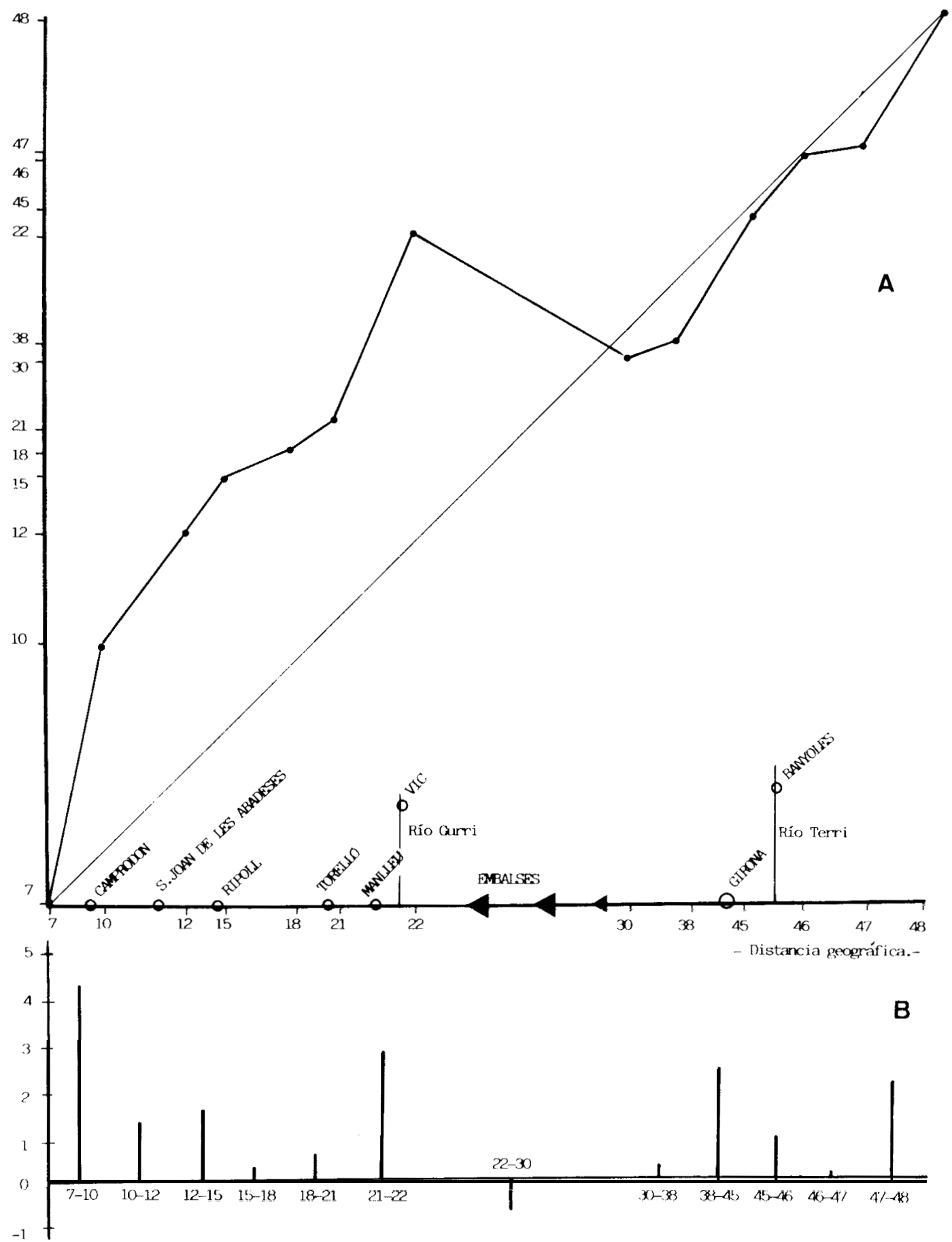

Figure 5.-A) Relationship between geographical and chernical (see text) distances of the different sampling stations of the Ter river. B) Rate of mineralization change between two successive stations expressed as the slope ofthe interconnecting line in figure A.

A) Relación entre las distancias geográfica y «química» (ver explicación en el texto) de las diferentes estaciones del eje del Ter. B) Tasa de cambio en la rnineralización que se produce entre dos estaciones consecutivas expresadas como la pendiente de la recta que une dichos puntos en la figura $\mathrm{A}$. 


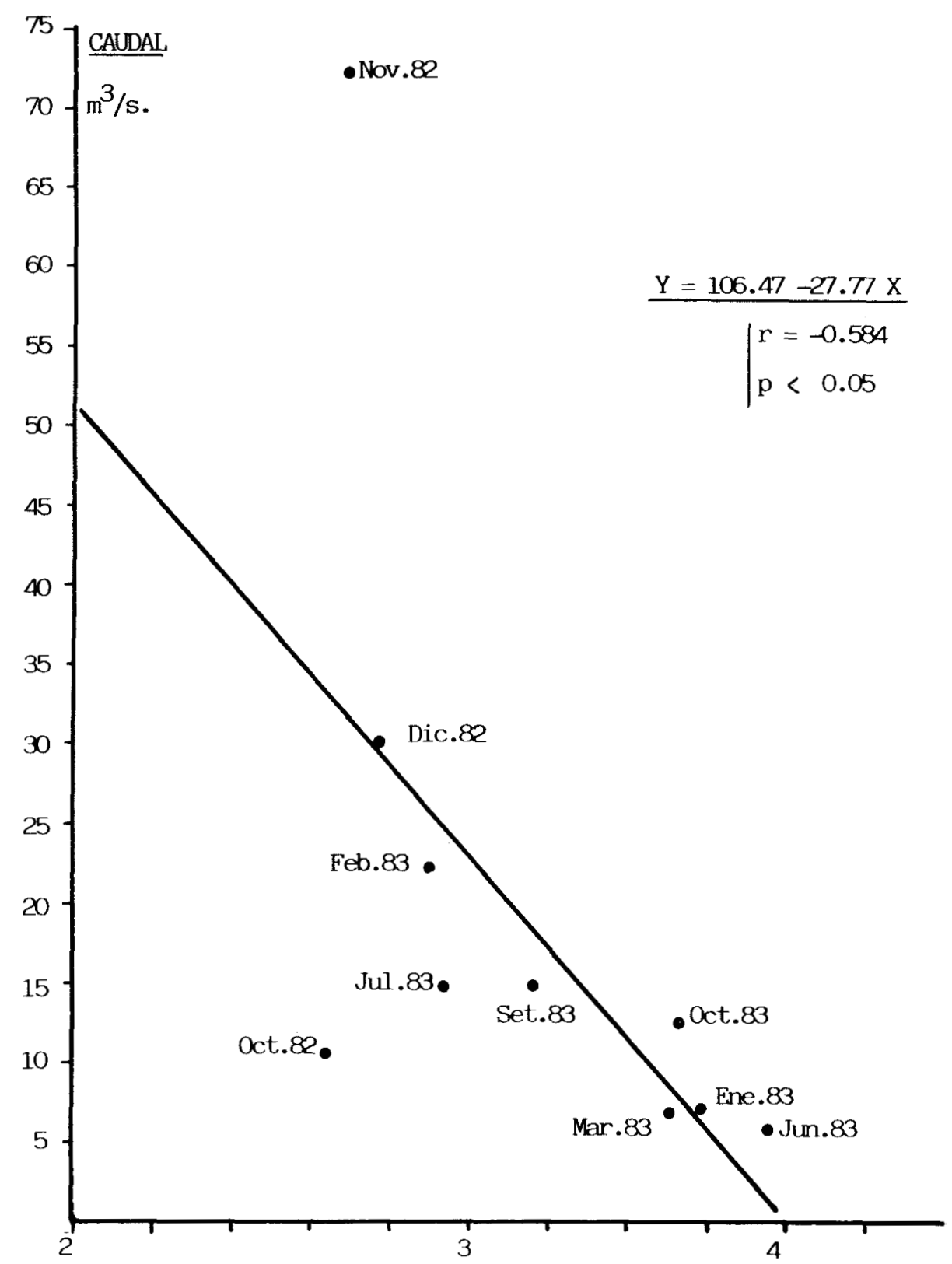

Figure 6.-Relationship between water flow of the river and the difference between the values of the first principal component of stations 47 and 7 ofdifferent times of the year.

Relación entre el caudal del río y la diferencia de los valores del primer componente principal entre las estaciones 47 y 7 en distintas épocas del año. 
can imagine that the river length, when considering the salt concentration is shorter during the larger waterflows and is longer when the level is lower.

From a functional point of view the river can be considered a continuum (Odum, 1956; Margalef, 1960; Vannote et al., 1980). In each point the environmental conditions are consequence of the processes taking place there in addition to the influence of those unstream. The dominance of one or the other is what enables us to distinguish continuity or disruption. Overlapping dominant process at each point is the inertia that the river progressively retains, and which confers an increase in homeostasis in such a way that a given perturbation will have a very different effect depending on where it takes place. Therefore, in the Ter river, small urban affluents in the source have proportionately larger effects than the junction with the Gurri, and these two greater than the inputs from Girona and its area of influence (Fig. 4 and 5).

We are now ready to complete the chemical characterization of the Ter river, as we know on one hand the structure in terms of the chemical composition, which parameters have greater incidence on the water composition, and on the other the dynamics expressed as rates of change in space and in time. Now the environmental setting needs only to be completed with the biological communities so as to have a description of this ecosystem in biological and environmental terms.

Throughout this study the contrast between the actual image of the river as it appears in the map, and the chemical image as envisioned through the water analyses, is used in an attempt to explain the structure and dynamics of the river. While repeatedly refering to chemical distances, a mental image of the river takes form. In this imaginary representation the river at dilated al the riverhead (7-12), then it contracts (15-21), jumps downstream (22), then backwards upstream (30-38) to flow calmly into the sea. At the same time, and superimposed over this image, the river shrinks and stretches following a more or less regular sequence in time.

\section{ACKNOW LEDGEMENTS}

Financial support the study the Ter river and its reservoirs has been provided by the CAICYT n. ${ }^{\circ}$ 478/81 project. We are indebted with Dr. J. Flos for his suggestions before writing the manuscript and also for his critical lecture. Our thanks are due to E. Carr for the translation of the Spanish manuscript.

\section{BIBLIOGRAFIA}

Capblanq, J. \& Tourenq, J.N. 1978. Hydrochimie de la riviere Lot. Annls. Limnol. 14: 25-37.

Estrada, M. 1975. Statistical considerations of some limnological parameters in Spanish reservoirs. Verh. Internat. Verein. Limnol. 19: 1849-1859.

Flos, J. 1979. Interpretación de varios análisis de componentes principales aplicados a un conjunto de datos oceanográficos de una zona meritica del golfo de Vizcaya. Inv. Pesq. 43: 611-635.

Gibbs, R.J. 1970. Mechanisms controlling world water chemistry. Science. 170: 1.088 .

Golterman, H. 1975. (River) chemistry. In Whitton, B. (Ed.). River ecology: 39-80. Blackwell. Oxford.

Golterman, H. 1982. La géochimie du Rhin et du Rhône et I'impact humain. Hydrobiologia. 91: 85-91. Gorham, E. 1961. Factors influencing supply of major ions to inland waters, with special reference to the atmosphere. Bull. Geol. Soc. Am. 72: 795-840.

Margalef, R. 1960. Ideas for a synthetic approach to the ecology of running waters. Int. Revue, ges. Hydrobiol. 45: 133-153.

1983. Limnologia. Ed. Omega. Barcelona. 1.010 PP.

Margalef, R.; Planas, D.; Armengol, J.; Vidal, A.; Prat, N.; Guiset, A.; Toja, J. y Estrada, M. 1976. Limnologia de los embalses españoles. Dirección General de Obras Hidráulicas, Ministerio de Obras públicas. Madrid. $422+85$ pp.

Meybeck, M. 1979. Concentrations des eaux fluviles es éléments majeurs et apports en solution aux océans. Revue de Géologie Dynamique et Géographie physique. 21: 215-246.

Odum, H.T. 1956. Primary production in flowing waters. Limnol. Oceanogr., 1: 102-117.

Puig, M.A.; González, G. y Recasens, L. 1985. Las comunidades de macroinvertebrados del río Ter, con especial referencia a Plecopteros, Efemerópteros, Tricópteros y Simulidos. III Congreso Español de Limnologia. León. 2-5 de julio de 1985.

Peñuelas, J. \& Sabater, F. 1985. Distribution of macrophytes in relation to environmental factors in the river Ter, N.E. Spain. IAB. Conference of Bryoecology. Budapest. 5-10 August, 1985.

Sabater, S. \& Sabater, F. 1984. Diatom communities of the middle part of the river Ter (Catalonia, NE Spain). Changes in space and time, and their relations with the physico-chemical parameters. VIII Symposium on Fosil and Living Diatoms, Paris, 1984. (en prensa).

Vannote, R.L.; Minshall, G.W.; Cummins, R.W.; Sedell, J.R. \& Cushing, C.E. 1980. The river continuum concept. Canad. J. Fish Aquat, Sci., 37: 130-137. 